
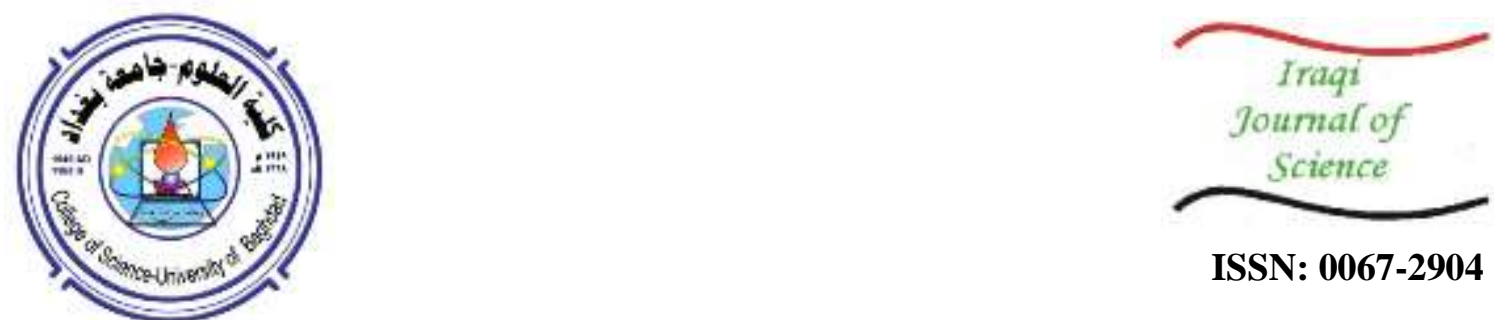

ISSN: 0067-2904

\title{
The prevalence of anemia among children infected with Entamoeba histolytica in Baghdad
}

\author{
Israa Naif Zeki, Harith Saeed Al-Warid* \\ Department of Biology, College of Science, University of Baghdad, Baghdad, Iraq
}

Received: 8/6/2019 Accepted: 27/7/2019

\begin{abstract}
The relation between Entamoeba histolytica and anemia has lately had much attention. The aim of this study was to determine the possible correlation between anemia and parasitic intestinal infection with E.histolytica in children from Baghdad-Iraq. This study was conducted from October 2018 to April 2019 in different hospitals, primary health care centers, and primary schools. Eighty-one children participated in this study and their ages were between 1 and 12 years. The participants were divided into two groups based on their general microscopic stool examination. The first group was diagnosed as E.histolytica infected group $(\mathrm{n}=47)$, while no pathogens were detected in the stool samples of the second group which was considered as a healthy control $(n=34)$. Blood samples were taken from all subjects and tested for haemoglobin level, serum ferritin, serum iron, total binding iron capacity (TBIC) and mean corpuscular volume (MCV). Nutritional status was also evaluated for all children aged $\geq 5$ years old. Results showed that the prevalence of anemia was higher in children infected with E.histolytica compared with the control subjects. Anemia was largely reported among children aged 1-3 years for both E.histolytica infected children and control subjects. The results also illustrated that both haemoglobin and iron levels were significantly $(\mathrm{p}<0.05)$ lower in E.histolytica infected children compared with control subjects, while non-significant differences $(\mathrm{p}>0.05)$ were observed in the level of ferritin between E.histolytica infected children and control subjects, although the ferritin was lower in E.hisolytica infected group. The results showed that both gender and age are significantly related to low serum iron levels in both infected and control groups. Significant relationshipswere also noticed between each of the anemia types and the nutritional status with the E.histolytca infection. Microcytic anemia as well as high records of severe malnutrition were observed in the majority of $E$. histolytica infected children These findings indicate that anemia is more expected to be present in children infected with E.histolytica. Therefore, efforts should be focused on health education of populations at high risk of both anemia and E.histolytica.
\end{abstract}

Keywords:Anemia, Entamoeba histolytica, Iraq.

$$
\begin{aligned}
& \text { انتثار فقر الام بين الاطفال المصابين بالاميبا الحالة للنسج في بغداد } \\
& \text { اسراء نايف زكي , حسارث سعيد الـورد } \\
& \text { قسم علوم الحياة، كلية العلوم، جامعة بغداد، بغداد، العراق اقل }
\end{aligned}
$$

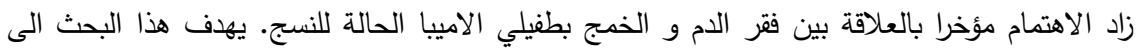

تحري العلاقة بين فقر الدم و الخمج بطفيلي الاميبا الحالة للنسج لادى مجموعة من الاطفال في بغداد-العراق.

*Email: harithalward @ scbaghdad.edu.iq 


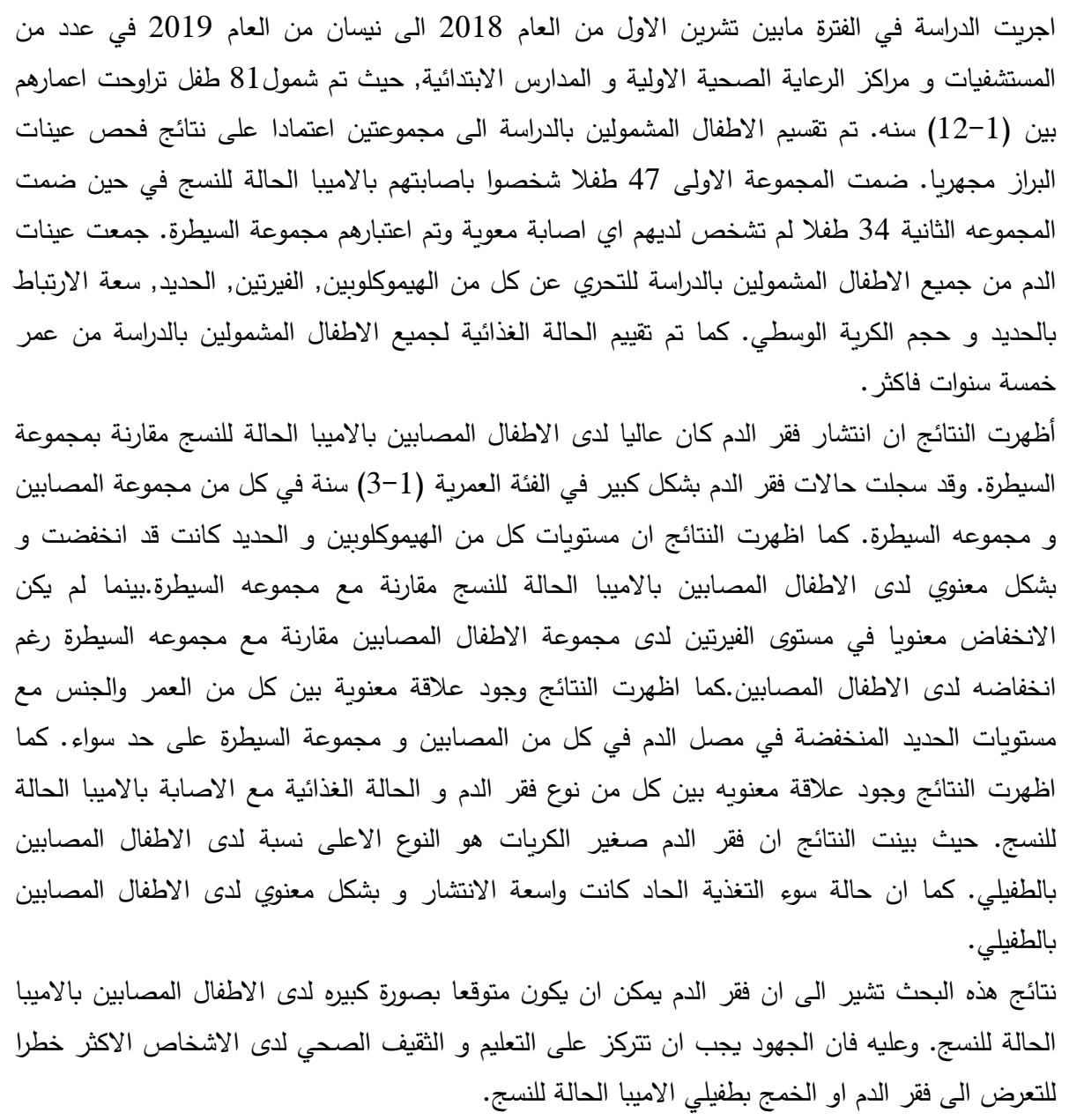

\section{Introduction}

Anemia is an abnormal haemoglobin level in blood resulted from various influences.It is the greatest common cause is iron deficiency[1].Consequently, anemia and iron deficiency anemia (IDA) are usually used synonymously, and the prevalence of anemia has frequently been used as an alternative for IDA [2]. It is mainly expected that about 50\% of the cases of anemia are due to iron deficiency, but the proportion may fluctuate among population groups and in different areas according to the local situations. The key risk factors for IDA consist of low intake of iron, poor absorption of iron from diets, and period of life when iron requirements are especially high [3].Anemia effects nearly $40 \%$ of school children in developing countries [4] and an important public health problem in Iraq, especially in children and adolescents [5-7]. No countrywide illustrative records are presented on the prevalence or occurrence of anemia among children in Baghdad, however, some local studies revealed an anemia prevalence of about 31.1\% [8]. Many influences contributing to anemia, which are increasing energy expenditure, irregularly eating habit, lacking maternal attention, and infections,particularly parasitic infections that are common in children[9]. Helminthic infections cause anemia by dropping iron uptake from the intestine[10], while protozoan parasites impact anemia by destructing the intestinal mucosa,which affects the absorption of micronutrients, such as iron [11]. Such mechanisms correspondingly affect hosts' nutritional grade and then change their immune system [12]. In Iraq, some studies were conducted to determine the association between iron deficiency anemia (IDA) and gastro-intestinal parasitic infections among children [13, 14].

Entamoeba histolytica is one of the most important and broadly prevalent protozoan parasites, causing significant public health and health problems in developing countries [15]. E. histolytica causes amoebic dysentery, amoebic colitis, and liver abscess, resulting in 100,000 deaths each year [16]. E. histolytica are often spread by contaminated food and/or drinking water and possibly from person to person through fecal oral contact [17]. Many papers reported different prevalence rates of $E$. histolytica in Iraq $[18,19]$, but little is known about its relation to anemia, especially in children. The 
aim of this study was to determine the possible correlation between anemia and parasitic intestinal infection with E.histolytica.

\section{Materials and Methods}

\section{Study design and study populations}

This study was an analytical case control study conducted from October 2018 until April 2019. The population in this study was children from both genders in some hospitals, primary health care centers and public primary schools in Baghdad, Iraq. Sampling included 81 participants who matched inclusion criteria and had no exclusion criteria. The inclusion criteria were children aged $\leq 12$ years, who were willing and had their parents' agreement to participate in this study. They also must not have been taking anti-helminth or anti-protozoa medication in the previous 24 weeks prior to the study and had no history of asthma, atopic dermatitis, immunodeficiency, malignancies, rheumatic disease, and other infections. Exclusion criteria were obesity and stool and blood samples that were impaired or missing. The study protocol was approved by the Ministry of Health and Environment, Baghdad, Iraq. A permission from primary school authority were also approved.

The 81 participants were divided into two groups based on their microscopic general stool examination which was done according to Truant et al.[20]. Stool samples were preserved in 10\% formalin before transporting to the laboratory, where they were examined under the light compound microscope. Diagnosis was confirmed by finding trophozoites or cysts of E. histolytica. The first group was diagnosed as E.histolytica infected children $(\mathrm{n}=47)$, while no pathogens were detected in the stool samples of the other group which was considered as the healthy control group $(n=34)$.

\section{Data Collection, Anthropometry and Nutritional status}

Interviews with parents were performed based on a prepared questionnaire to obtain information about background characteristics of children as well as the children's past and present illnesses. Body weight and height were measured using standardized procedures [21] and recorded as the midpoint of duplicate measurements. Children's weight was measured by an electronic scale (IndiaMart, India) and their standing height was measured with a wooden stadiometer (CMS equipment Ltd, UK). The children had minimum clothing and no shoes. Body Mass Index (BMI), which is the weight in kilograms of a person divided by the square of the height in meters, was used to evaluate the nutritional status of the children, which was classified into severe malnutrition $\left(B M I<15.9 \mathrm{~kg} / \mathrm{m}^{2}\right)$, moderate and mild malnutrition $\left(\mathrm{BMI}=16-18.4 \mathrm{~kg} / \mathrm{m}^{2}\right)$ and normal $\left(\mathrm{BMI}=18.5-25 \mathrm{~kg} / \mathrm{m}^{2}\right)[21]$. The nutritional status was evaluated only for children aged $\geq 5$ years old.

\section{Blood samples and hematology}

About $4-5 \mathrm{~mL}$ of blood was taken using a venipuncture technique, collected in a tube containing EDTA as an anticoagulant, reserved in an ice container, and transported to the laboratory. All blood samples were analysed in less than 12 hours after blood collection. Haemoglobin concentration and mean corpuscular volume (MCV) were measured using Celtac Es MEK-7300K (NIHOB KODHEN, Germany) automatic hematology analyzer. Serum ferritin and total binding iron capacity (TBIC)were measured using IMMULITE 2000 XPi Immunoassay System (Siemens, Germany). Serum iron was measured using Dimensions X pand plus (Siemens, Germany). All these tests were performed according to their manufacturer's instructions.

\section{Statistical Analysis}

All the collected data were analyzed using SPSS 16.0 (SPSS Inc., Chicago, IL, USA). Data is defined in the distribution of frequencies then analyzed using Chi- Square $\left(\chi^{2}\right)$ to determine whether there is an association between each of anemia, type of anemia, and nutritional status with E.histolytica infection. Then, all data variables, including haemoglobine, ferritin and serum iron were analyzed using student t-test to evaluate whether there is any statistically significant difference between E.histolytica infected children and the control group. The differences were considered significant with p-value 0.05 (CI 95\%).

\section{Results}

Eighty one children were enrolled in this study. The age distribution was 1 to 12 years. Twenty six children were between 1 to 3 years old, 29 were between 4 to 6 years old, 14 were between 7 to 9 years old, and 12 were between 10 to 12 years old. Forty nine were males and 32 females. Results showed that the mean (SD) haemoglobin was $121.79 \mathrm{~g} / 1(13.6)$ with a range between $82 \mathrm{~g} / \mathrm{l}$ and 145 g/l. Twenty two children (26.7\%) had anemia (haemoglobin $<115 \mathrm{~g} / \mathrm{L}$ )according to the WHO definition. The mean (SD) of haemoglobin $118 \mathrm{~g} / \mathrm{L}(12.8)$ was significantly lower $(\mathrm{p}=0.014)$ in 
E.histolytica infected children compared with the mean of haemoglobin $125 \mathrm{~g} / \mathrm{L}(13.7)$ in the control group (Figure-1).

The prevalence of anemia was higher in patients infected with E.histolytica (29.78\%) compared with the control subjects who showed less prevalence rate of anemia (23.52\%). Statistical analysis indicated no significant difference in the prevalence of anemia between E.histolytica infected children and control group $(\mathrm{p}>0.05)$. Anemia was largely reported among those aged 1-3 years old for both E.histolytica infected children and control subjects. The statistical analysis showed no significant relation between age and prevalence of anemia in both E.histolytica infected children and control subjects among all age groups $(\mathrm{p}>0.05)$ (Table-1). Moreover no significant relation was noticed between gender and prevalence of anemia in E.histolytica infected children and control subjects ( $>0.05)$ (Table-2).

Results showed that the mean (SD) of ferritin level was lower $16.4 \mu \mathrm{g} / \mathrm{mL}$ (24.7) in E.histolytica infected children compared with the mean of ferritin $23.6 \mu \mathrm{g} / \mathrm{mL}$ (17.9) in the control group (Figures- 2, 3). Although non-significant differences were noticed in ferritin level between E.histolytica infected children and control group, low ferritin level had significantly $(\mathrm{p}=0.002)$ high distribution in E.histolytica infected children. Results showed that 30 out of 47 (63.82\%) E.histolytica infected children had low ferritin levels while the low ferritin levels were noticed only in $29.4 \%$ of the control group. No significant differences were noticed regarding ferritin level between E.histolytica infected children and control group for all age groups, except in the age group of 4-6 years (Table-3). In this age group, significantly lower ferritin level was $(\mathrm{p}=0.02)$ recorded in E.histolytica infected children. No significant relation was noticed between gender and low ferritin level (Table-4).

The mean (SD) level of serum iron was significantly lower $(\mathrm{p}=0.0001)$ in E.histolytica infected children, with a value of $23.5 \mu \mathrm{g} / \mathrm{mL}$ (16.7), compared with the mean of serum iron $65.5 \mu \mathrm{g} / \mathrm{mL}$ (26.7) in the control group. The results showed that $93.6 \%$ of E.histolytica infected children had low iron level which was noticed in only $29.4 \%$ of the control group. Low serum iron level was largely reported among those aged 7-9 and 10-12 years for both E.histolytica infected children and control subjects (Table-5). The statistical analysis showed significant relations between age and low serum iron level in both E.histolytica infected children and the control subjects ( $>0.05)$. Also, significant relationswere noticed between gender and low serum iron level in both E.histolytica infected children and the control subjects ( $>0.05$ ) (Table-6). The results also showed that the mean (SD) of TIBC was lower in E.histolytica infected children, with a value of $349 \mu \mathrm{g} / \mathrm{dL}$ (92), compared with a high TIBC level of $364 \mu \mathrm{g} / \mathrm{dL}$ (78.4) in the control group. No significant differences $(\mathrm{p}>0.05)$ were noticed in TICB between E.histolytica infected children and the control subjects.

Table-7 illustrates the distribution of anemia according to MCV values among the cases of E.histolytica and the control group. Microcytic anemia $(\mathrm{MCV}<82 \mathrm{fL})$ was seen in the majority of $E$. histolytica infected children compared with fewer cases in the control group. On the other hand,normocytic anemia (MCV $=82-98 \mathrm{fL}$ ) was noticed in the majority of the control group compared with less cases in E.histolytica infected children. No cases of macrocytic anemia (MCV $>98 \mathrm{fL}$ ) were seen among both infected and control groups. Statistical analysis showed that there was a significant relation $(\mathrm{p}<0.05)$ between the type of anemia and the infection with E.histolytica.

Nutritional status was evaluated in this study only for children aged more than 5 years old. Results showed that 23 out of 24 (95.9\%) ofE.histolytica infected children had severe malnutrition $\left(\mathrm{BMI}<15.9 \mathrm{~kg} / \mathrm{m}^{2}\right)$ compared with $62.5 \%$ of the control group. No normal nutritional status $\left(\mathrm{BMI}=18.5-25 \mathrm{~kg} / \mathrm{m}^{2}\right)$ was noticed in E.histolytica infected children while only one case with normal nutritional status was reported in the control group (Table-8). Statistical analysis showed that there was significant relation $(\mathrm{p}<0.05)$ between the nutritional status and the infection with E.histolytica. 

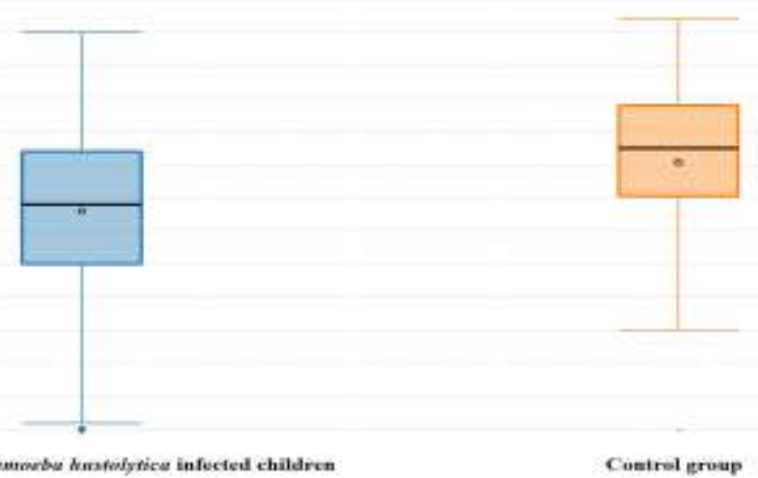

Figure 1- Haemoglobin concentration $(\mathrm{g} / \mathrm{L})$ in E.histolytica infected children and the control group.

Table 1-Prevalence of anemia based on haemoglobin concentration, related to age for patients infected with E.histolytica and the control group.

\begin{tabular}{|c|c|c|c|c|c|}
\hline & \multicolumn{2}{|c|}{ Cases with Entamoeba histolytica } & \multicolumn{2}{|r|}{ Control group } & \multirow[b]{2}{*}{ P-value } \\
\hline $\begin{array}{c}\text { Age } \\
\text { group/years }\end{array}$ & $\begin{array}{l}\text { No. of } \\
\text { tested }\end{array}$ & $\begin{array}{c}\text { Prevalence of anemia } \\
\text { (Haemoglobin concentration } \\
<115 \mathrm{~g} / \mathrm{L} \text { ), \% }\end{array}$ & $\begin{array}{l}\text { No. of } \\
\text { tested }\end{array}$ & $\begin{array}{c}\text { Prevalence of anemia } \\
\text { (Haemoglobin concentration } \\
<115 \mathrm{~g} / \mathrm{L} \text { ), \% }\end{array}$ & \\
\hline $1-3$ & 20 & $8(40 \%)$ & 6 & $2(33 \%)$ & 0.25 \\
\hline 4-6 & 18 & $4(22.2 \%)$ & 11 & $3(27 \%)$ & 0.75 \\
\hline $7-9$ & 4 & $1(16 \%)$ & 10 & $2(20 \%)$ & 0.82 \\
\hline $10-12$ & 5 & $1(20 \%)$ & 7 & $1(14.2)$ & 0.79 \\
\hline Total & 47 & $14(29.78 \%)$ & 34 & $8(23.52 \%)$ & 0.24 \\
\hline
\end{tabular}

Table 2- Prevalence of anemia, based on haemoglobin concentration, related to gender for patients infected with E.histolytica and the control group.

\begin{tabular}{|c|c|c|c|c|c|}
\hline & \multicolumn{2}{|c|}{ Cases with Entamoeba histolytica } & \multicolumn{2}{c|}{ Control group } & Prevalence of anemia \\
\hline Gender & $\begin{array}{c}\text { No. of } \\
\text { tested }\end{array}$ & $\begin{array}{c}\text { Prevalence of anemia } \\
\text { (Haemoglobin concentration } \\
<\mathbf{1 1 5 g} / \mathbf{L}), \%\end{array}$ & $\begin{array}{c}\text { No. of } \\
\text { tested }\end{array}$ & $\begin{array}{c}\text { Premoglobin concentration } \\
\text { <115g/L ), \% }\end{array}$ & P-value \\
\hline Male & 26 & $10(38.46 \%)$ & 23 & $4(17.93 \%)$ & 0.1 \\
\hline Female & 21 & $4(19.4 \%)$ & 11 & $4(36.36 \%)$ & 0.2 \\
\hline Total & 47 & $14(29.78 \%)$ & 34 & $8(23.52 \%)$ & 0.24 \\
\hline
\end{tabular}
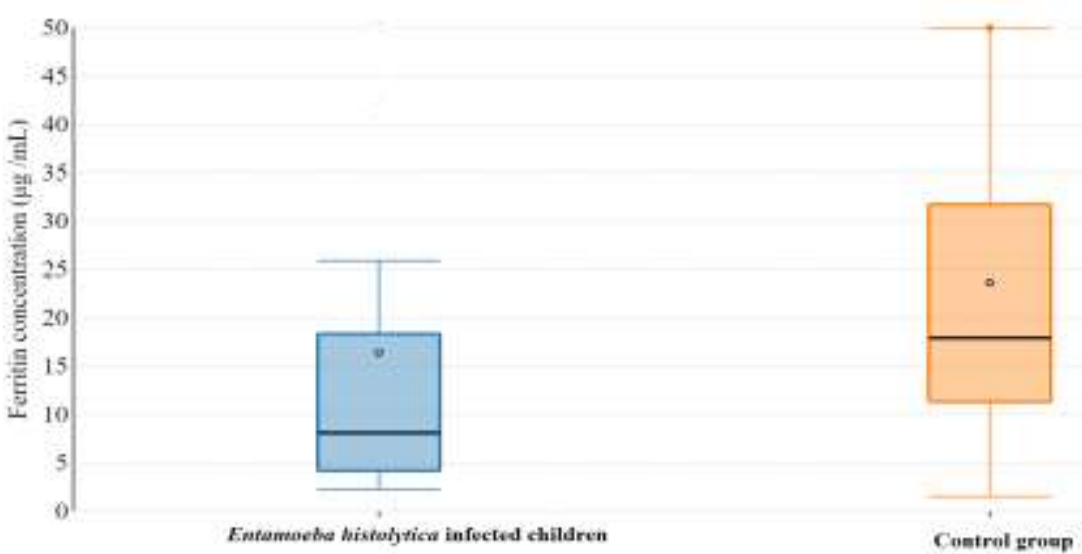

Figure 2-Ferritin concentration $(\mu \mathrm{g} / \mathrm{mL})$ in E.histolytica infected children and the control group. 
Table 3- Percentage of low ferritin level related to age for patients infected with E.histolytica and the control group.

\begin{tabular}{|c|c|c|c|c|c|}
\hline & \multicolumn{2}{|c|}{ Cases with Entamoeba histolytica } & \multicolumn{2}{|c|}{ Control group } & \\
\hline $\begin{array}{c}\text { Age } \\
\text { group/years }\end{array}$ & $\begin{array}{c}\text { No. of } \\
\text { tested }\end{array}$ & $\begin{array}{c}\text { Low ferritin level } \\
(<\mathbf{1 2} \boldsymbol{\mu g} / \mathbf{m L}), \mathbf{\%}\end{array}$ & $\begin{array}{c}\text { No. of } \\
\text { tested }\end{array}$ & $\begin{array}{c}\text { Low ferritin } \\
\text { level(<12 } \boldsymbol{\mu g} / \mathbf{m L}) \mathbf{\%} \%\end{array}$ & P-value \\
\hline $\mathbf{1 - 3}$ & 20 & $14(70 \%)$ & 6 & $1(16.6 \%)$ & 0.4 \\
\hline $\mathbf{4 - 6}$ & 18 & $11(61.1 \%)$ & 11 & $2(18.1 \%)$ & 0.02 \\
\hline $\mathbf{7 - 9}$ & 4 & $2(50 \%)$ & 10 & $4(40 \%)$ & 0.7 \\
\hline $\mathbf{1 0 - 1 2}$ & 5 & $3(60 \%)$ & 7 & $3(42.8 \%)$ & 0.8 \\
\hline Total & 47 & $30(63.82 \%)$ & 34 & $10(29.4 \%)$ & 0.002 \\
\hline
\end{tabular}

Table 4- Percentage of low level of ferritin related to gender for patients infected with E.histolytica and the control group.

\begin{tabular}{|c|c|c|c|c|c|}
\hline \multirow[b]{2}{*}{ Gender } & \multicolumn{2}{|c|}{ Cases with Entamoeba histolytica } & \multicolumn{2}{|r|}{ Control group } & \multirow[b]{2}{*}{ P-value } \\
\hline & $\begin{array}{l}\text { No. of } \\
\text { tested }\end{array}$ & $\begin{array}{l}\text { Low ferritin level } \\
(<12 \mu \mathrm{g} / \mathrm{mL}), \%\end{array}$ & $\begin{array}{l}\text { No. of } \\
\text { tested }\end{array}$ & $\begin{array}{c}\text { Low ferritin } \\
\text { level }(<12 \mu \mathrm{g} / \mathrm{mL}), \%\end{array}$ & \\
\hline Male & 26 & $16(61.5 \%)$ & 23 & $8(34 \%)$ & 0.6 \\
\hline Female & 21 & $14(66.6 \%)$ & 11 & $2(18.18 \%)$ & 0.2 \\
\hline Total & 47 & $30(63.82 \%)$ & 34 & $10(29.4 \%)$ & 0.002 \\
\hline
\end{tabular}

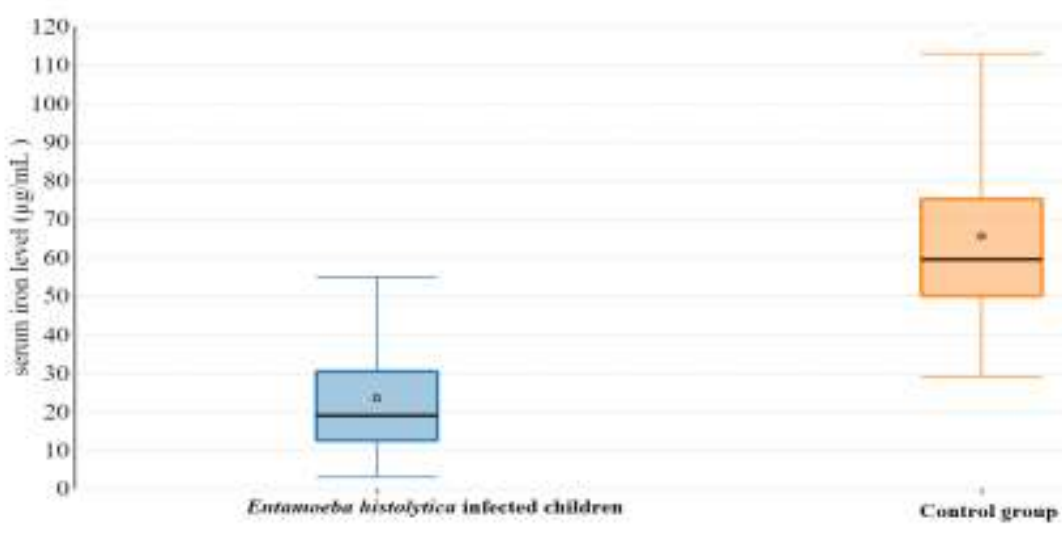

Figure 3-Serum iron concentrtion $(\mu \mathrm{g} / \mathrm{mL})$ in E.histolytica infected children and the control group.

Table 5- Percentage of low serum iron level related to age for patients infected with E.histolytica and the control group.

\begin{tabular}{|c|c|c|c|c|c|}
\hline & \multicolumn{2}{|c|}{ Cases with Entamoeba histolytica } & \multicolumn{2}{|c|}{ Control group } & \\
\hline $\begin{array}{c}\text { Age } \\
\text { group/years }\end{array}$ & $\begin{array}{c}\text { No. of } \\
\text { tested }\end{array}$ & $\begin{array}{c}\text { Low serum iron level } \\
(<\mathbf{5 0} \boldsymbol{\mu} \mathbf{g} / \mathbf{m L}), \boldsymbol{\%}\end{array}$ & $\begin{array}{c}\text { No. of } \\
\text { tested }\end{array}$ & $\begin{array}{c}\text { Low serum iron level } \\
(<\mathbf{5 0} \boldsymbol{\mu g} / \mathbf{m L}) \mathbf{\%}\end{array}$ & P-value \\
\hline $\mathbf{1 - 3}$ & 20 & $19(95 \%)$ & 6 & $1(16.6 \%)$ & 0.00006 \\
\hline $\mathbf{4 - 6}$ & 18 & $16(88.8 \%)$ & 11 & $3(27.27 \%)$ & 0.0007 \\
\hline $\mathbf{7 - 9}$ & 4 & $4(100 \%)$ & 10 & $3(30 \%)$ & 0.017 \\
\hline $\mathbf{1 0 - 1 2}$ & 5 & $5(100 \%)$ & 7 & $3(42.85 \%)$ & 0.03 \\
\hline Total & 47 & $44(93.6 \%)$ & 34 & $10(29.4 \%)$ & 0.00 \\
\hline
\end{tabular}


Table 6- Percentage of low serum iron level related to gender for patients infected with E.histolytica and the control group.

\begin{tabular}{|c|c|c|c|c|c|}
\hline & \multicolumn{2}{|c|}{ Cases with Entamoeba histolytica } & \multicolumn{2}{|c|}{ Control group } & \\
\hline Gender & $\begin{array}{c}\text { No. of } \\
\text { tested }\end{array}$ & $\begin{array}{c}\text { Low serum iron level } \\
(<\mathbf{5 0} \boldsymbol{\mu} \mathbf{g} / \mathbf{m L}), \boldsymbol{\%}\end{array}$ & $\begin{array}{c}\text { No. of } \\
\text { tested }\end{array}$ & $\begin{array}{c}\text { Low serum iron level } \\
(<\mathbf{5 0} \boldsymbol{\mu g} / \mathbf{m L}), \%\end{array}$ & P-value \\
\hline Male & 26 & $25(96.1 \%)$ & 23 & $8(34.7 \%)$ & 0.000004 \\
\hline Female & 21 & $19(90.4 \%)$ & 11 & $2(18.18 \%)$ & 0.0004 \\
\hline Total & 47 & $44(93.6 \%)$ & 34 & $10(29.4 \%)$ & 0.00 \\
\hline
\end{tabular}

Table 7- The types of anemia based on MCV for patients infected with E.histolytica and the control group.

\begin{tabular}{|c|c|c|}
\hline Type of anemia based on MCV & $\begin{array}{c}\text { Cases with Entamoeba } \\
\text { histolytica }\end{array}$ & Control group \\
\hline $\begin{array}{l}\text { Microcytic anemia } \\
\operatorname{MCV}<82 \mathrm{fL}\end{array}$ & $39(82.9 \%)$ & $3(8.82 \%)$ \\
\hline $\begin{array}{l}\text { Normocytic anemia } \\
\text { MCV }=82-98 \mathrm{fL}\end{array}$ & $8(17.1 \%)$ & $31(91.17 \%)$ \\
\hline $\begin{array}{c}\text { Macrocytic anemia } \\
\text { MCV }>98 f \mathrm{~L}\end{array}$ & 0 & 0 \\
\hline Total & 47 & 34 \\
\hline
\end{tabular}

Table 8- Nutritional status for patients infected with E.histolytica and the control group.

\begin{tabular}{|c|c|c|}
\hline Nutritional status based on Body mass index & $\begin{array}{c}\text { Cases with Entamoeba } \\
\text { histolytica }\end{array}$ & Control group \\
\hline Severe malnutrition $\left(B M I<15.9 \mathrm{~kg} / \mathrm{m}^{2}\right)$ & $23(95.9 \%)$ & $15(62.5 \%)$ \\
\hline $\begin{array}{l}\text { Moderate, Mild malnutrition }(\mathrm{BMI}=16-18.4 \\
\left.\mathrm{kg} / \mathrm{m}^{2}\right)\end{array}$ & $1(4.1 \%)$ & $8(33.3 \%)$ \\
\hline Normal $\left(B M I=18.5-25 \mathrm{~kg} / \mathrm{m}^{2}\right)$ & 0 & $1(4.1 \%)$ \\
\hline Total & 24 & 24 \\
\hline \multicolumn{3}{|c|}{$\chi^{2}=8.129 ; \mathrm{P}-$ value $=0.017$} \\
\hline
\end{tabular}

\section{Discussion}

Anemia is a worldwide health problem that affects many people in each socioeconomic status, all over the world. In Iraq, anemia is an important public health issue, mainly in children and adolescents [5-7]. Nonetheless, there was few national data on the prevalence of anemia among children [6]. In the present study, $26.7 \%$ of children were found to be anaemic $(\mathrm{Hb}<115 \mathrm{~g} / \mathrm{L})$. This prevalence rate among children could be associated with poor nutrition and some other factors [22]. The results showed that the haemoglobin level was significantly lower in E.histolytica infected children compared with that in the control group. In addition, the prevalence of anemia, depending on haemoglobin level, was higher (29.78\%) in E.histolytica infected children compared with the control group. E.histolytica interacts to the mucous layer of the small intestine, resulting in villous atrophy in different levels, beside triggering inflammatory infiltrate and crypt hypertrophy. These processes disrupt the enterocytes and change bile acid metabolism that affects the absorption of most nutrients which are essential for body function, such as vitamins, iron, zinc, and folic acid[23]. Such results are similar to the results of Koukounari et al. (2008) [24] who reported prevalence of anemia in Kenyan schoolchildren with some 
intestinal parasitic infections. Also, Al-Zubaydi (2002) [25] found that 37\% of anemic subjects had gastrointestinal parasitic infection. Moreover, Al-Naemi et al. (2011) [26] and Al-Warid et al. (2013) [14] found a relationship between anemia and parasitic infections in Mosul province and in Baghdad province, respectively. All previous studies showed high prevalence of anemia in subjects infected with gastrointestinal parasites.

The results of the current study showed that anemia was largely reported in children aged 1-3years compared to school children. This finding might be attributed to the benefit of school children having a good education regarding taking good food supplemented with iron and other minerals [27]. Therefore, haemoglobin levels in school children are likely to be within normal values. The increased risk of anemia in children below the age of 3 years is consistent with the results from other countries $[28,29]$.Ferritin level was lower in E.histolytica infected children compared with the control group. Low ferritin levels were significantly highly prevalent in E.histolytica infected children $(63.82 \%)$ compared with their less prevalence rate $(29.4 \%)$ in the control group. The low ferritin level in children infected with E.histolytica is likely due to the ability of the trophozoite of this parasite to utilize ferritin as an iron source [30]. These results are in agreement with the results of Al-Warid et al., (2013)who illustrated that ferritin was higher in non-infected children with E.histolytica while the infected children showed low levels of ferritin [14]. Moreover, these results agreed with the results of Le et al., (2007) who showed that ferritin was in its low level in children infected with some intestinal parasites [31]. On the other hand, the results disagreed with the results of Silva et al.,(2009) who showed that ferritin levels were greatly higher in infected children with Giardia lamblia when compared with non-infected children [32].The differences between the findings in the present study and the other studies are likely due to age, the species of parasite and the sample size. Serum iron was significantly lower in E.histolytica infected children compared with its levels in the control group.The results showed that $93.6 \%$ of E.histolytica infected children had low iron level,which was noticed only in $29.4 \%$ of the control group. These findings agree with the results of other studies $[14,33]$, which showed significant differences for serum iron between children with and without some intestinal parasites. E. histolytica needs great levels of iron to stay alive. This parasitic protozoan has the ability to gain iron from the host proteins [34], thus, heavy infection with E. hostolytica may cause a decline in iron level in the host. These results were confirmed by TIBC test which showed that the infected group had less TIBC level than normal, which is an indicator of too little iron in the blood of infected children with E.histolytica.The results showed that microcytic anemia was seen in the majority of E.histolytica infected children compared with fewer cases in the control group. While normocytic anemia was noticed in the majority of the control group compared with a high percentage in E.histolytica infected children. No cases of macrocytic anemia were seen among both infected and control groups. These results can be explainable by the notion thatmicrocytic anemia is almost entirely related to chronic infections while normocytic anemia is related to iron deficiency [35]. These results might likely be a good indicator of the relation between anemia and infection with gastro intestinal parasite. The results showed that $95.9 \%$ of E.histolytica infected children had severe malnutrition $\left(\mathrm{BMI}<15.9 \mathrm{~kg} / \mathrm{m}^{2}\right)$ compared with the control group who showed less percentage of malnutrition. This result agreed with the results of Ammare et al., (2013) who showed that children with lower body weight and height were more infected with intestinal parasites than children with higher anthropometric parameters [21].

Nonetheless, our findings may provide some guidelines for investigators assessing management approaches for the control of both anemia and infection with E.histolytica. In addition, the findings from this research suggest a relationship between anemia and E.histolytica in children.

\section{References}

1. Özdemir, N. 2015. Iron deficiency anemia from diagnosis to treatment in children. Turkish Archives of Pediatrics, 50(1): 11.

2. Clark, S.F. 2008. Iron deficiency anemia. Nutrition in clinical practice, 23(2): 128-141.

3. De Benoist, B., Cogswell, M., Egli, I. and McLean, E., 2008. Worldwide prevalence of anaemia 1993-2005; WHO Global Database of anaemia.

4. Assefa, S., Mossie, A. and Hamza, L. 2014. Prevalence and severity of anemia among school children in Jimma Town, Southwest Ethiopia. BMC hematology, 14(1): 3. 
5. Ahmad, H.M. 2016. Anemia and Iron Deficiency Anemia Prevalence with Serum Zinc assessment among Emigrated Yazidis People in Khanki camp in Duhok city, Kurdistan Region, Iraq. IOSR J Dental Medical Science, 15: 105-10.

6. Ali, F.J.D. and Al-Ani, A.S. 2009. Prevalence of Iron Deficiency Anemia among Adolescents Intermediate School Pupils in Ramadi District. Iraqi Journal of Community Medicine, 22(3): 158162.

7. Al-Sharbatti, S.S., Al-Ward, N.J. and Al-Timimi, D.J. 2003. Anemia among adolescents. Saudi medical journal, 24(2): 189-194.

8. Abdulhameed, S.A., Abdulmajeed, K.H. and Muslim, M.I. 2016. Prevalence of Anemia in Children below 5 Years in Al-Mansoor Family Medicine Primary Health Center in Baghdad. Iraqi Medical Journal, 62(2): 190-195.

9. World Health O. 2001. Iron deficiency anemia. assessment, prevention, and control. A guide for programme managers, pp.47-62.

10. Adebara, O.V., Ernest, S.K. and Ojuawo, I.A. 2011. Association between intestinal helminthiasis and serum ferritin levels among school children. Open Journal of Pediatrics, 1(02): 12.

11. Gopalakrishnan, S., Eashwar, V.A., Muthulakshmi, M. and Geetha, A. 2018. Intestinal parasitic infestations and anemia among urban female school children in Kancheepuram district, Tamil Nadu. Journal of family medicine and primary care, 7(6): 1395.

12. Mohammadi, R., Hosseini-Safa, A., Ardakani, M.J.E. and Rostami-Nejad, M. 2015. The relationship between intestinal parasites and some immune-mediated intestinal conditions. Gastroenterology and hepatology from bed to bench, 8(2): 123.

13. AL-Qadhi, B.N. and AL-Warid, H.S. 2012. Anemia and Enterobiasis among Iraqi children. Journal of Basic Education College/Al-Mustansiriyah University, 18(76): 57-62.

14. Al-Warid, H.S., Musa, I.S. and Al-Qadhi, B.N. 2013. Iron deficiency and antropometry in children infected with Entamoeba histolytica. International Journal of Recent Scientific Research, 4(6): 823-826.

15. Fletcher, S.M., Stark, D., Harkness, J. and Ellis, J. 2012. Enteric protozoa in the developed world: a public health perspective. Clinical microbiology reviews, 25(3): 420-449.

16. Haque, R., Huston, C.D., Hughes, M., Houpt, E. and Petri Jr, W.A. 2003. Amebiasis. New England journal of medicine, 348(16): 1565-1573.

17. Duc, P.P., Nguyen-Viet, H., Hattendorf, J., Zinsstag, J., Cam, P.D. and Odermatt, P. 2011. Risk factors for Entamoeba histolytica infection in an agricultural community in Hanam province, Vietnam. Parasites \& vectors, 4(1): 102.

18. Al Saqur, I.M., Al-Warid, H.S. and Albahadely, H.S. 2017. The prevalence of Giardia lamblia and Entamoeba histolytica/dispar among Iraqi provinces. Karbala International Journal of Modern Science, 3(2): 93-96.

19. Al-Warid, H.S. 2012. Some Factors Influencing the Prevalence of Gairdia lamblia and Entamoeba histolytica in a Sample of Patients in North of Baghdad. Journal of Al-Nahrain University-Science, 15(2): 121-125.

20. Truant, A.L., Elliott, S.H., Kelly, M.T. and Smith, J.H. 1981. Comparison of formalin-ethyl ether sedimentation, formalin-ethyl acetate sedimentation, and zinc sulfate flotation techniques for detection of intestinal parasites. Journal of clinical microbiology, 13(5): 882-884.

21. Amare, B., Ali, J., Moges, B., Yismaw, G., Belyhun, Y., Gebretsadik, S., Woldeyohannes, D., Tafess, K., Abate, E., Endris, M. and Tegabu, D. 2013. Nutritional status, intestinal parasite infection and allergy among school children in Northwest Ethiopia. BMC pediatrics, 13(1): 7.

22. Aspuru, K., Villa, C., Bermejo, F., Herrero, P. and López, S.G. 2011. Optimal management of iron deficiency anemia due to poor dietary intake. International journal of general medicine, 4: 741750.

23. Calvao, F., Costa Gileno, D., Malta, J.O., Vientini, V. and Anibal, F. 2011. Anemia in patients with intestinal parasitic infection. Revista Ibero-latinoamericana de parasitología, 70(2): 206-211.

24. Koukounari, A., Estambale, B.B., Njagi, J.K., Cundill, B., Ajanga, A., Crudder, C., Otido, J., Jukes, M.C., Clarke, S.E. and Brooker, S. 2008. Relationships between anaemia and parasitic infections in Kenyan schoolchildren: a Bayesian hierarchical modelling approach. International journal for parasitology, 38(14): 1663-1671. 
25. Al-Zubaydi ZH. 2002 .Hookworm Ancylostoma duodenale infection and its effect on blood picture in Mishamish village in Babylon province. M.Sc. Thesis, College of Science, Babylon University, pp. 112.

26. Al-Naemi, B.S., Rahemo, Z.I.F. and Al-Kalak, S.N. 2011. Relationship between anemia and parasitic infections in Shekhan district, Iraq, Journal of Research in Biology, 5: 319-324.

27. Jung, T., Huang, J., Eagan, L. and Oldenburg, D. 2019. Influence of school-based nutrition education program on healthy eating literacy and healthy food choice among primary school children. International Journal of Health Promotion and Education, 57(2): 67-81.

28. Austin, A.M., Fawzi, W. and Hill, A.G. 2012. Anaemia among Egyptian Children between 2000 and 2005: trends and predictors. Maternal \& child nutrition, 8(4): 522-532.

29. Semedo, R.M., Santos, M.M., Baião, M.R., Luiz, R.R. and da Veiga, G.V. 2014. Prevalence of anaemia and associated factors among children below five years of age in Cape Verde, West Africa. Journal of health, population, and nutrition, 32(4): 646.

30. López-Soto, F., González-Robles, A., Salazar-Villatoro, L., León-Sicairos, N., Piña-Vázquez, C., Salazar, E.P. and de la Garza, M. 2009. Entamoeba histolytica uses ferritin as an iron source and internalises this protein by means of clathrin-coated vesicles. International journal for parasitology, 39(4): 417-426.

31. Le, H.T., Brouwer, I.D., Verhoef, H., Nguyen, K.C. and Kok, F.J. 2007. Anemia and intestinal parasite infection in school children in rural Vietnam. Asia Pacific Journal of Clinical Nutrition, 16(4): 716-723.

32. Silva, R.R., da Silva, C.A.M., de Jesus Pereira, C.A., de Carvalho Nicolato, R.L., Negrão-Corrêa, D., Lamounier, J.A. and Carneiro, M. 2009. Association between nutritional status, environmental and socio-economic factors and Giardia lamblia infections among children aged 6-71 months in Brazil. Transactions of the Royal Society of Tropical Medicine and Hygiene, 103(5): 512-519.

33. Olivares, J.L., Fernandez, R., Fleta, J., Ruiz, M.Y., Clavel, A. and Moreno, L.A. 2004. Iron deficiency in children with Giardia lamblia and Enterobius vermicularis. Nutrition research, 24(1): 1-5.

34. López-Soto, F., León-Sicairos, N., Reyes-López, M., Serrano-Luna, J., Ordaz-Pichardo, C., PiñaVázquez, C., Ortiz-Estrada, G. and de la Garza, M. 2009. Use and endocytosis of iron-containing proteins by Entamoeba histolytica trophozoites. Infection, Genetics and Evolution, 9(6): 10381050.

35. Chulilla, J.A.M., Colás, M.S.R. and Martín, M.G. 2009. Classification of anemia for gastroenterologists. World Journal of Gastroenterology: WJG, 15(37): 4627. 